\title{
Role of shame in the stigmatization of people with human immunodeficiency virus: a survey of female college students in 3 Arab countries
}

A.M. Badahdah ${ }^{7}$ and C.E. Foote ${ }^{2}$

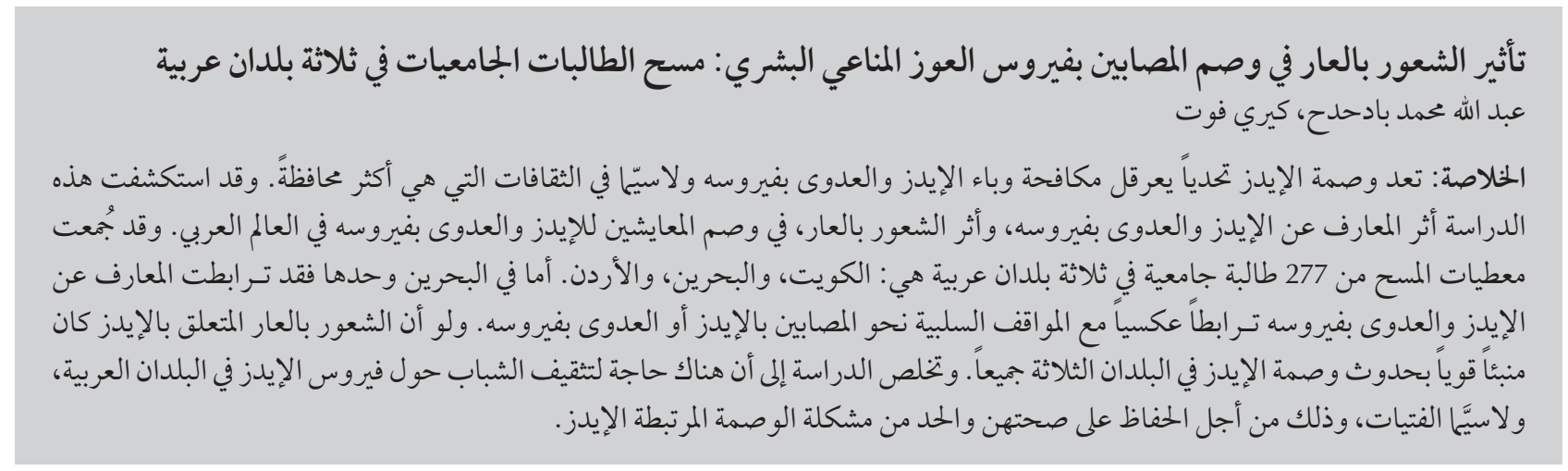

ABSTRACT AIDS stigma is a challenge to controlling the HIV/AIDS epidemic especially in more conservative cultures. This study explored the impact of knowledge about HIV and AIDS, and the impact of shame, on the stigmatization of people living with HIV/AIDS in the Arab world. Survey data were collected from 277 female college students in 3 Arab countries: Kuwait, Bahrain and Jordan. Only in Bahrain was knowledge about HIV and AIDS inversely related to negative attitudes toward people with HIV/AIDS. AIDS-related shame, however, was a strong predictor of AIDS stigma in all 3 countries. HIV education is needed for young people in Arab countries, especially women, both for their own health and to reduce the problem of AIDS stigma.

Rôle de la honte dans la stigmatisation des personnes atteintes du virus de l'immunodéficience humaine : étude réalisée sur des lycéennes dans trois pays arabes

RÉSUMÉ La stigmatisation du sida constitue un obstacle en matière de lutte contre l'épidémie de VIH/sida, en particulier au sein des cultures conservatrices. Cette étude portait sur les conséquences du niveau de connaissance sur le VIH et le sida et de la honte suscitée par la maladie, sur la stigmatisation des personnes vivant avec le VIH/ sida dans le monde arabe. Les données de cette étude ont été recueillies auprès de 277 étudiantes dans trois pays arabes : Bahreïn, la Jordanie et le Koweït. Bahreïn s'est révélé le seul pays où le niveau de connaissance sur le VIH/sida est inversement proportionnel aux attitudes négatives à l'égard des personnes vivant avec le virus. La honte associée au sida constitue toutefois un facteur prédictif important de la stigmatisation de la maladie dans les trois pays. L'éducation en matière de VIH est nécessaire auprès des jeunes des pays arabes, notamment des femmes, tant pour préserver leur propre santé que pour réduire le problème de la stigmatisation du sida.

'Department of Sociology, University of North Dakota, Grand Forks, North Dakota, United States of America (Correspondence to A.M. Badahdah: abdallah.badahdah@und.nodak.edu).

${ }^{2}$ Department of Sociology, Indiana University-Purdue University, Indianapolis, Indiana, United States of America.

Received: 15/01/09; accepted: 23/03/09 


\section{Introduction}

Deeply held cultural values, such as disapproval of nonmarital sex and of drug use, have been accredited with slowing the spread of HIV infection in Arab societies until now. Yet, more recently, these same cultural values have been blamed for the increase of HIV cases which is being seen in these societies. This seemingly contradictory view rests on the idea that the intense disapproval ofsuch behaviour will discourage people from being tested for HIV or pursuing adequate care or treatment when they need it $[1-4]$. These factors have led to a growing awareness that reducing AIDS stigma is critical to effective HIV prevention and treatment [5].

In the Arab world, women are at heightened risk for HIV infection because of their socially disadvantaged position in society. Lack of independent income and low literacy curtails women's ability to access HIV information, to ward off unwanted sexual advances and to negotiate safe sexual practices $[6,7]$. Indeed, Arab women now represent half the total number of people carrying the virus in the region and nearly $80 \%$ of affected women contracted the virus from their husbands [8].

Although genuine attempts have been made to raise AIDS awareness by authorities in the Arab region, they are comparatively meagre $[1,9]$. In particular, they fail to address the population's continued lack of access to good HIV information. Young adults are likely to be the most negatively affected because they are at the life stage where risky behaviour, such as having unprotected sex or experimenting with drugs, is most likely to take place [1]. Studies of college students in Jordan and United Arab Emirates (UAE) found alarming gaps in HIV and AIDS knowledge and negative attitudes towards people with HIV/ AIDS [10-12]. All 3 studies found that male students had greater knowledge than female students. However, these and other studies in Saudi Arabia,
Yemen and Kuwait [13-16] focused largely on the impact of knowledge about HIV and AIDS on AIDS stigma; none paid close attention to the role of emotion in AIDS stigma.

Some researchers have suggested that certain emotions are triggered at the introduction of the topic of AIDS, and that these emotional responses remain among the most challenging barriers to reducing stigmatization [17]. One of these emotions is shame, which was found in to be a significant factor that caused HIV-positive individuals to hide their health status from their caregivers and to withdraw from social interactions $[3,18,19]$. Two recent studies from Saudi Arabia and Yemen suggest that the emotion of shame may be particularly salient in understanding the stigmatization of people with HIV/ AIDS in the Arab world and that feeling ashamed that a friend or family member has HIV may be among the strongest predictors of stigmatization $[16,18]$.

In view of the lack of AIDS research in the Arab region and the increasing vulnerability of Arab women to HIV, the present study sought to assess gaps in younger Arab women's HIV/AIDS knowledge, along with their conceptions of shame, and their reactions toward people with HIV/AIDS. To this end we collected and compared data from female college students from Kuwait, Bahrain and Jordan. Specifically, we wanted to investigate whether knowledge about HIV and AIDS, on the one hand, and shame on the other, had any effect on tolerance towards persons with HIV/AIDS.

\section{Methods}

\section{Sample}

Three convenience samples of female undergraduate students from colleges in Kuwait, Bahrain and Jordan completed a self-administered questionnaire written in Arabic. Participation in the research was voluntary and no payment or curricular credit was given for participation. The samples consisted of 83 students from Kuwait, 108 from Bahrain and 86 from Jordan.

\section{Data collection}

A questionnaire consisting of 13 items was used to gauge participants' knowledge of HIV transmission and AIDS (Table 1). These items were adapted from the Attitudes Towards AIDS Knowledge Scale [20] which has been used for college students. The items covered 3 areas: behavioural and situational risk factors (5 items); fluids that carry HIV and risk reduction steps (4 items); and misconceptions about HIV and AIDS (4 items). Each item had 3 choices: "true," "false" and "don't know": a score of 1 was assigned to the correct answer and 0 to an incorrect or "don't know" answer. Therefore, the higher the score a respondent received, the greater that participant's knowledge about HIV and AIDS.

In the AIDS literature there are 2 items that have been frequently used in assessing the expression of shame associated with AIDS [21]: being ashamed of having a family member with HIV/ AIDS and the belief that people with HIV/AIDS should be ashamed of themselves. In this study we added a third item that assessed shame at the national level by asking the participants if they would be ashamed of having a fellow citizen with HIV/AIDS. Again, responses were recorded on a 5-point Likert scale and the higher the score a respondent received, the greater the respondent's expression of AIDS-related shame.

We measured the dependent variable, AIDS stigma, with 7 items [21]. Theseincluded: people with HIV/AIDS should be fired from their jobs; people with HIV/AIDS should be quarantined; I am sympathetic toward people with HIV/AIDS; I have no objection to marrying into a family with HIV/AIDS; I do not mind being touched by someone with HIV/AIDS; all people with 


\begin{tabular}{|c|c|c|c|c|c|c|}
\hline \multirow[t]{2}{*}{ Knowledge item } & \multicolumn{2}{|c|}{ Kuwait $(n=83)$} & \multicolumn{2}{|c|}{ Bahrain $(n=108)$} & \multicolumn{2}{|c|}{ Jordan $(n=86)$} \\
\hline & No. correct & $\%$ & No. correct & $\%$ & No. correct & $\%$ \\
\hline $\begin{array}{l}\text { One can get HIV by having sex with an HIV-positive } \\
\text { person }\end{array}$ & 83 & 100 & 108 & 100 & 83 & 97 \\
\hline $\begin{array}{l}\text { One can get HIV by sharing HIV-contaminated } \\
\text { needles }\end{array}$ & 81 & 98 & 105 & 97 & 80 & 93 \\
\hline $\begin{array}{l}\text { An infected mother can transmit HIV during } \\
\text { pregnancy }\end{array}$ & 73 & 88 & 98 & 91 & 77 & 90 \\
\hline One can get HIV by touching someone with AIDS & 59 & 71 & 92 & 85 & 41 & 48 \\
\hline Only homosexuals get AIDS & 62 & 75 & 82 & 76 & 51 & 59 \\
\hline $\begin{array}{l}\text { HIV can live in the human body for years before } \\
\text { symptoms appear }\end{array}$ & 54 & 65 & 75 & 69 & 30 & 35 \\
\hline There is a cure for AIDS & 53 & 64 & 74 & 69 & 53 & 62 \\
\hline $\begin{array}{l}\text { You can tell if someone has AIDS by looking at } \\
\mathrm{him} / \mathrm{her}\end{array}$ & 49 & 59 & 71 & 66 & 40 & 47 \\
\hline $\begin{array}{l}\text { Unsafe anal sex is the most risky sexual act for } \\
\text { contracting HIV }\end{array}$ & 37 & 45 & 59 & 55 & 45 & 52 \\
\hline $\begin{array}{l}\text { An infected mother can transmit HIV through } \\
\text { breastfeeding }\end{array}$ & 43 & 52 & 34 & 31 & 44 & 51 \\
\hline A mosquito bite can transmit HIV & 13 & 16 & 29 & 27 & 15 & 17 \\
\hline HIV can be transmitted through semen & 22 & 27 & 24 & 22 & 44 & 51 \\
\hline $\begin{array}{l}\text { Condoms help reduce the probability of HIV } \\
\text { transmission }\end{array}$ & 18 & 22 & 20 & 19 & 15 & 17 \\
\hline
\end{tabular}

HIV are responsible for their infection; and if a friend of mine got infected with HIV, I would continue being a friend with him/her.

Responses were recorded on a 5-point Likert scale that ranged from "strongly disagree" to "strongly agree". After reversing the score values for those statements that read sympathetically toward people with AIDS, the scores were tallied as before. The higher the score, the more negative attitudes students held toward people with AIDS.

\section{Analysis}

SPSS, version 17 , was used for both descriptive and inferential statistics. A $P$-value of $<0.05$ was considered statistically significant.

\section{Results}

\section{Demographic data}

The ages of the Kuwaiti women $(n=83)$ ranged from 18 to 26 years, with a mean age of 20.6 [standard deviation (SD) $1.4]$ years, while the Bahraini $(n=108)$ and Jordanian women $(n=86)$ ranged from 18 to 28 years, with mean ages of $21.4($ SD 1.9) years and $19.8(\mathrm{SD}=1.9)$ years respectively. Most of the women were single: $90 \%$ of the Kuwaitis, $79 \%$ of the Bahrainis and $97 \%$ of the Jordanians. Overall a total of 33 women were married and 1 was divorced.

\section{HIV and AIDS knowledge}

Table 1 reports the frequency of correct answers to the HIV and AIDS knowledge items of the respondents by country. Nearly all the students correctly identified the main behaviours or situations that place people at risk for HIV, i.e. sex with an HIV-positive person, intravenous drug use with a contaminated needle and being carried to term by an infected pregnant woman (range 88\%-100\% answered correctly). However, while most students could correctly identify the behavioural risks of transmission, they were much less knowledgeable about the fluids that carry HIV. A large proportion of the women were unaware that HIV could be transmitted through semen (only $23 \%$ of Bahraini, $27 \%$ of Kuwaiti and $51 \%$ of Jordanian women answered correctly) or through mother's breast milk (32\% of Bahraini, 52\% of Kuwaiti and $51 \%$ of Jordanian women answered correctly).

A number of other misconceptions about HIV and AIDS were also evident. About $30 \%$ of the women in each country believed there was a cure for AIDS, 63\%-73\% believed one could get HIV from a mosquito bite and a striking 78\%-83\% were unaware that condoms could help reduce the chance of HIV infection.

Assigning a "correct score" for each question answered correctly by at least half of participants in each sample yielded the following pattern. The sample of Bahraini women answered 9/13 questions correctly (69\%), the Kuwaitis $7 / 13$ (54\%) and the Jordanians 6/13 
(46\%). These variations in HIV and AIDS knowledge among the samples were statistically significant (ANOVA, $F(2,278)=4.78, P=0.009)$. The Tukey test revealed that Bahraini students had significantly higher knowledge [mean score 8.06 (SD 1.88)] than the Kuwaiti and Jordanian students [mean scores 7.79 (SD 2.20) and 7.18 (SD 1.89) respectively].

\section{HIV shame and stigma measures}

Table 2 shows the means scores for the shame and stigma items from the 3 countries. Looking at the stigma items the highest mean scores for the Kuwaiti and Bahraini students was for the item about isolating HIV-positive people from society. For the Jordanian students, the highest mean score was for having no objection to marrying into a family with HIV/AIDS. For the shame items, the highest mean score for all 3 groups was agreement with the statement "I would be ashamed of having people with HIV/AIDS in my country".
Cronbach alpha values for the shame measure for the 3 countries were acceptable $(0.74,0.62$ and 0.77 for the Kuwaiti, Bahraini and Jordanian students respectively). There were no statistically significant differences between the 3 samples in the shame measure [ANOVA, $F(2,274)=1.30, P=0.23$ ].

For the stigma measure, the reliabilities for all samples were acceptable and comparable (Cronbach alpha values were $0.72,0.72$ and 0.75 for the $\mathrm{Ku}$ waitis, the Bahrainis and the Jordanians respectively). There were no statistically significant differences among the samples $[F(2,274)=0.92, P=0.40]$.

\section{Correlations between measures}

For the Bahraini students, the knowledge index was negatively correlated with the AIDS stigma scale $(r=-0.38)$ but was unrelated to the AIDS-related shame items $(r=-0.08)$. In the women from Kuwait and Jordan, the knowledge index was uncorrelated with the AIDS stigma scale $(r=-0.09, r=-0.15$ respectively) and AIDS-related shame scale $(r=-0.08, r=-0.12$ respectively). However, the AIDS stigma scale and the AIDS-related shame scale were positively correlated for all 3 samples (Bahrainis $r=0.49$, Kuwaitis $r=0.59$, Jordanians $r=0.59$ ).

\section{Multiple regression analysis}

Multiple regression analysis was performed to predict participants' level of tolerance towards people with HIV/ AIDS based on their knowledge of HIV and AIDS and AIDS-related shame for each sample (Table 3)

For the Kuwaiti students AIDSrelated shame was the only predictor of stigmatization of people with HIV/ AIDS $(\beta=0.59, P<0.001)$. For the Bahraini women AIDS-related shame was the best predictor of AIDS stigma $(\beta=0.46, P<0.001)$. Students who perceived AIDS to be a shameful disease expressed more negative attitudes toward people with HIV/AIDS. Knowledge of HIV and AIDS was also a good predictor $(\beta=-0.34, P<0.001)$ : students

\begin{tabular}{|c|c|c|c|c|c|c|}
\hline \multirow[t]{2}{*}{ Item } & \multicolumn{2}{|c|}{$\begin{array}{l}\text { Kuwait } \\
(n=83)\end{array}$} & \multicolumn{2}{|c|}{$\begin{array}{l}\text { Bahrain } \\
(n=108)\end{array}$} & \multicolumn{2}{|c|}{$\begin{array}{l}\text { Jordan } \\
(n=86)\end{array}$} \\
\hline & $\begin{array}{l}\text { Mean } \\
\text { score }\end{array}$ & SD & $\begin{array}{l}\text { Mean } \\
\text { score }\end{array}$ & SD & $\begin{array}{l}\text { Mean } \\
\text { score }\end{array}$ & SD \\
\hline \multicolumn{7}{|l|}{ Stigma } \\
\hline People with HIV/AIDS should be fired from their jobs & 3.53 & 1.27 & 3.24 & 1.18 & 3.15 & 1.28 \\
\hline People with HIV/AIDS should be quarantined & 4.09 & 1.03 & 3.88 & 1.07 & 3.52 & 1.29 \\
\hline I am sympathetic toward people with HIV/AIDS & 2.54 & 1.15 & 3.02 & 1.16 & 2.82 & 1.19 \\
\hline $\begin{array}{l}\text { I have no objection to marrying into a family with } \\
\text { HIV/AIDS }\end{array}$ & 3.81 & 1.22 & 3.58 & 1.29 & 4.29 & 1.01 \\
\hline $\begin{array}{l}\text { I do not mind being touched by someone with } \\
\text { HIV/AIDS }\end{array}$ & 3.97 & 1.21 & 3.73 & 1.23 & 4.17 & 1.07 \\
\hline All people with HIV are responsible for their infection & 2.50 & 1.36 & 2.30 & 1.27) & 2.08 & 1.40 \\
\hline $\begin{array}{l}\text { If a friend of mine got infected with HIV I would } \\
\text { being a friend with him/her }\end{array}$ & 2.89 & 1.33 & 3.23 & 1.19 & 3.18 & 1.21 \\
\hline \multicolumn{7}{|l|}{ Shame } \\
\hline Ashamed of having a relative with HIV/AIDS & 3.61 & 1.18 & 3.53 & 1.19 & 3.26 & 1.44 \\
\hline $\begin{array}{l}\text { People with HIV/AIDS should be ashamed } \\
\text { of themselves }\end{array}$ & 3.32 & 1.31 & 3.23 & 1.18 & 3.17 & 1.31 \\
\hline $\begin{array}{l}\text { Ashamed of having people with HIV/AIDS } \\
\text { in my country }\end{array}$ & 3.69 & 1.18 & 3.58 & 1.17 & 3.46 & 1.41 \\
\hline
\end{tabular}

$S D=$ standard deviation. 


\begin{tabular}{|c|c|c|c|}
\hline \multicolumn{4}{|c|}{$\begin{array}{l}\text { Table } 3 \text { Multiple regression analysis of AIDS stigma of female college students in } 3 \\
\text { Arab countries }\end{array}$} \\
\hline Predictor & B & SE B & $\beta$ \\
\hline \multicolumn{4}{|l|}{ Kuwait } \\
\hline AIDS-related shame & 0.432 & 0.067 & $0.587^{* *}$ \\
\hline Knowledge of AIDS & -0.014 & 0.030 & -0.043 \\
\hline \multicolumn{4}{|l|}{ Bahrain } \\
\hline AIDS-related shame & 0.380 & 0.064 & $0.464^{* *}$ \\
\hline Knowledge of AIDS & -0.133 & 0.031 & $-0.341^{* *}$ \\
\hline \multicolumn{4}{|l|}{ Jordan } \\
\hline AIDS-related shame & 0.385 & 0.060 & $0.576^{* *}$ \\
\hline Knowledge of AIDS & -0.034 & 0.036 & -0.083 \\
\hline
\end{tabular}

$\mathrm{R}^{2}=0.35$ for Kuwait, 0.36 for Bahrain and 0.35 for Jordan .

**P $<0.001$.

$S E=$ standard error

with greater knowledge about HIV and AIDS tended to view individuals with HIV/AIDS less negatively. In Jordanian students, AIDS-related shame was a significant predictor of AIDS stigma $(\beta$ $=0.58, P<0.001)($ Table 3$)$.

\section{Discussion}

Our results suggest that participants had inaccurate knowledge of the kinds of behaviours that could transmit HIV. Bahraini participants were more knowledgeable than the participants from both Kuwait and Jordan. However, the majority of participants from all 3 countries were unable to identify the correct answers to several items. Their lack of knowledge about 2 items in particular is alarming. All 3 groups had trouble providing the correct answers to the items on condom use and the possible transmission of HIV in semen. More specifically, more than $75 \%$ of the participants in each sample did not know or gave the wrong answer about the role of condoms in minimizing the risk of HIV infection. Similarly, $73 \%$ of Kuwaiti, $78 \%$ of Bahraini and $49 \%$ of Jordanian female students did not know that HIV can be carried in semen.

One possible explanation for these results is the taboos regarding the topic of sexuality in the Arab world. Women are discouraged from seeking information about sex and about the proper way to protect themselves from sexually transmitted infections [7]. In addition, there is almost no education about sex in the schools [9]. Another plausible reason for these specific gaps in knowledge about HIV and AIDS is that HIV prevention efforts in the Arab world focus strongly on abstinence, and place little if any emphasis on the role of condoms [22].

Knowledge about HIV and AIDS played an influential role in the Bahraini women's reactions toward people with HIV/AIDS, but not in those of the other 2 groups. This is not surprising since the Bahraini women in this study had greater knowledge about HIV and AIDS. The findings therefore indicate that accurate knowledge about HIV and AIDS can play a powerful role in minimizing the stigmatization of people with HIV/ AIDS. Therefore, as shown elsewhere [23,24], improving HIV and AIDS-related knowledge is one way to decrease AIDS stigma in the Arab region.

The most intriguing and unique feature of this study was the role of shame in predicting the negative attitudes towards people with HIV/AIDS. Whereas the HIV and AIDS-related knowledge was predictive of negative attitudes toward persons with HIV/ AIDS only among the Bahraini women, shame related to AIDS was predictive across all 3 samples. The link between shame and AIDS may be due to the association between HIV/AIDS and such socially undesirable activities such as unlawful sex and drugs in the Arab world. If so, people with HIV/AIDS are considered a source of shame and should be avoided for the sake of one's reputation.

Studies about AIDS stigma have reported that family and caregivers of people with HIV/AIDS suffer from courtesy stigma (stigma by association) and have been the target of ridicule and discrimination $[25,26]$.

Courtesy stigma may be particularly detrimental in Arab culture because shame is an especially powerful emotion that plays a major role in this society. Indeed, Arab culture has been labelled a shame-oriented culture because shame is an intensely feared emotion and often results in the social isolation of the shamed individual, if not their murder [27]. Thus, it seems that fear of shame, not for one's wrongdoing, but for being associated with someone with HIV/AIDS, is the main reason women in this study stigmatized people with HIV/AIDS.

Because our study focused on young college women with small convenience samples, The ability to generalize from it is limited. The findings of this study, however, point to a need for more studies that examine the role of shame in the stigmatization of people with HIV/AIDS. Studies with bigger samples of both males and females and from other countries in the Arab world are needed.

\section{Conclusion}

This study provides evidence of an urgent need to provide HIV education to young people in Arab countries, especially women, for their own sake and to reduce AIDS stigma. Reducing the shame associated with HIV/AIDS may prove to be one of the key strategies towards improving the situation of people with HIV/AIDS in the Arab world. 


\section{References}

1. Fortenberry JD et al. Relationships of stigma and shame to gonorrhea and HIV screening. American Journal of Public Health, 2002, 92(3):378-381.

2. Kalichman SC, Simbayi LC. HIV testing attitudes, AIDS stigma, and voluntary HIV counselling and testing in a black township in Cape Town, South Africa. Sexually Transmitted Infections, 2003, 79(6):442-447.

3. Rintamaki LS et al. Social stigma concerns and HIV medication adherence. AIDS Patient Care and STDs, 2006, 20(5):359-368.

4. Roudi-Fahimi F. Time to intervene: preventing the spread of HIV AIDS in the Middle East and North Africa. Washington DC, Population Reference Bureau, 2007:1-8.

5. Holzemer WL, Uys LR. Managing AIDS stigma. Journal of Social Aspects of HIV/AIDS, 2004, 1(3):165-174.

6. Akala F, Jenkins C. Preventing HIV/AIDS in the Middle East and North Africa: a window of opportunity to act (Orientations in Development Series). Washington DC, World Bank, 2005:1-110.

7. Dejong J et al. The sexual and reproductive health of young people in the Arab countries and Iran. Reproductive Health Matters, 2005, 13(25):49-59.

8. Arab human development report: challenges to human security in the Arab countries. New York, United Nations Development Programme, Regional Bureau for Arab States, 2009.

9. El Feki S. Middle-Eastern AIDS efforts are starting to tackle taboos. Lancet, 2006, 367:975-996.

10. Petro-Nustas W. University students' knowledge of AIDS. International Journal of Nursing Studies, 2000, 37(5):423-433.

11. Petro-Nustas W, Kulwicki A, Zumout AF. Students' knowledge, attitudes, and beliefs about AIDS: a cross-cultural study. Journal of Transcultural Nursing, 2002, 13(2):118-125.

12. Gańczak M et al. Break the silence: HIV/AIDS knowledge, attitudes, and educational needs among Arab university students in United Arab Emirates. Journal of Adolescent Health, 2007, 40(6):572.e1-572.e8.

13. Al-Ghanim SA. Exploring public knowledge and attitudes towards HIV/AIDS in Saudi Arabia. A survey of primary health care users. Saudi Medical Journal, 2005, 26(5):812-818.

14. Al-Owaish R et al. Knowledge, attitudes, beliefs, and practices about HIV/AIDS in Kuwait. AIDS Education and Prevention, 1999, 11(2):163-173.
15. Al-Serouri AW et al. Knowledge, attitudes and beliefs about HIV/AIDS in Sana'a, Yemen. Eastern Mediterranean Health Journal, 2002, 8(6):706-715.

16. Badahdah A. Saudi attitudes towards people living with HIV/ AIDS. International Journal of STD and AIDS, 2005, 16(12):837838.

17. Link BG, Phelan JC. Conceptualizing stigma. Annual Review of Sociology, 2001, 27:363-385.

18. Badhadah A, Sayem N, Foote C. Development of a Yemeni AIDS Stigma Scale. AIDS Care, 2009, 21(6):754-759.

19. Cunningham SD et al. Attitudes about sexual disclosure and perceptions of stigma and shame. Sexually Transmitted Infections, 2002, 78(5):334-338.

20. Goh D. The development and reliability of the Attitudes Towards AIDS Scale. Paper presented at the Annual Meeting of the American Psychiatric Association, San Francisco, May 16-21, 2009

21. Nyblade LC. Measuring HIV stigma: existing knowledge and gaps. Psychology, Health and Medicine, 2006, 11(3):335-345.

22. Madani TA et al. Epidemiology of the human immunodeficiency virus in Saudi Arabia: 18-year surveillance results and prevention from an Islamic perspective. BMC Infectious Diseases, 2004, 4:25

23. Chen $\mathrm{J}$ et al. The effects of individual- and community-leve knowledge, beliefs, and fear on stigmatization of people living with HIV/AIDS in China. AIDS Care, 2007, 19(5):666-673.

24. Brown L, Trujillo L, Macintyre K. Interventions to reduce HIV/ AIDS stigma: what have we learned? AIDS Education and Prevention, 2001, 15(1):49-69.

25. Mwinituo PP, Mill JE. Stigma associated with Ghanaian caregivers of AIDS patients. Western Journal of Nursing Research, 2006, 28(4):369-382.

26. Greene K, Banerjee SC. Disease-related stigma: comparing predictors of AIDS and cancer stigma. Journal of Homosexuality, 2006, 50(4):185-209.

27. Glidden HW. The Arab world. American Journal of Psychiatry, 1972, 128(8):984-988. 